Revised Draft

January 16, 2004

Comments Solicited

\title{
The Changing Nature of Faculty Employment*
}

\author{
by
}

\section{Ronald G. Ehrenberg and Liang Zhang*}

(To be presented at the TIAA-CREF Institute conference on "Retirement, Retention and Recruitment", New York, NY, April 1-2, 2004))

* Ehrenberg is the Irving M. Ives Professor of Industrial and Labor Relations and Economics at Cornell University and Director of the Cornell Higher Education Research Institute (CHERI). Zhang is a graduate research assistant at CHERI. Without implicating them for what remains, we are grateful to the Andrew W. Mellon Foundation and the Atlantic Philanthropies (USA) Inc. for their financial support of CHERI. 


\section{Introduction}

The last two decades of the twentieth century saw a significant growth in the shares of faculty members in American colleges and universities that are part-time or are full-time without tenure-track status (Eugene Anderson 2002, Roger Baldwin and Jay Chronister 2001, Valerie Conley, David Lesley, and Linda Zimbler 2002). Growing student enrollments faced by academic institutions during tight financial times and growing differentials between the salaries of part-time and full-time non-tenure track faculty on the one hand, and tenured and tenure-track faculty on the other hand are among the explanations given for these trends. However, there have been few econometric studies that seek to test these hypotheses. ${ }^{1}$

Our paper begins by presenting information, broken down by form of control (public/private) and 1994 Carnegie Category, on how the proportions of full-time faculty at 4-year American colleges and universities that are tenured and on tenure tracks and that are not on tenure tracks have changed since 1989, using information for a consistent sample of institutions from the annual IPEDS Faculty Salary Surveys and the biennial IPEDS Fall Staff Surveys. The latter source also permits us to present similar estimates of the proportions of faculty that are employed part-time and the share of new full-time faculty appointments that are not on tenure tracks.

To analyze the role that economic variables play in causing changes in faculty employment across categories, we conduct two types of econometric analyses. First, in section III, we use panel data to estimate demand functions for tenure and tenure-track faculty on the one hand and full-time non tenure-track faculty on the other hand to learn

\footnotetext{
${ }^{1}$ Ronald G. Ehrenberg and Daniel B. Klaff (2002) provide some preliminary evidence using data from the State University of New York (SUNY) system.
} 
how changes in revenues per student and the average salaries of different types of fulltime faculty influence the distribution of faculty across categories of full-time faculty. We do this using both equilibrium models that assume instantaneous adjustments to changes in revenues and faculty salaries and lagged adjustment models that permit partial adjustments to equilibrium each year.

Second, in section IV, we estimate models that seek to explain the flow of new hires of each type of faculty member (rather than the levels of faculty employment) using data on new hires that are available from the IPEDS Fall Staff Surveys. To explain new hires, in addition to information on changes in revenues per student, changes in enrollment, and the levels of faculty salaries, we require information on the number of vacant positions that are available to be potentially filled. We construct information on the latter using data on the number of continuing full-time faculty members at an institution each year that the American Association of University Professors (AAUP) collects (but does not publish) as part of its annual salary survey.

Continuing faculty members in a rank are defined as the number of faculty members in a rank one year, who also are on the payroll of the institution in the next year, regardless of their rank in the second year. Summing up an institution's continuing faculty members across ranks in a year and subtracting that number from the institution's total faculty employment in the previous year provides us with an estimate of the number of full-time faculty vacancies that an institution could have filled in a year if it had replaced each of its departing full-time faculty members.

A brief concluding section summarizes our findings and discusses their implications for American colleges and universities and their students. 


\section{Changes in Faculty Composition}

Table 1 provides annual data on the share of full-time faculty members that are not employed in tenured or tenure-track positions at 4-year colleges and universities in the United States for the 1989 to 1999 period. The data come from the annual IPEDS Faculty Salary Surveys and are tabulated separately by form of control and 1994 Carnegie Category. Because a few institutions fail to report survey data each year, we restrict our attention to a sample of 504 public and 854 private colleges and universities that responded to the survey each year.

In the aggregate, the ratio of full-time non-tenure track faculty to total full-time faculty rose from 0.111 to 0.137 at the public institutions in the sample and from 0.142 to 0.197 at the private institutions in the sample. Contrary to what one might have expected, given the well-known budget problems of public higher education during the period, the increasing usage of full-time non tenure-track faculty was larger at the privates than at the publics. Moreover, for almost all Carnegie Categories, the share of full-time faculty that is not on tenure tracks was higher in 1999 at private institutions than it was at public institutions. $^{2}$

Appendix table 1 provides similar tabulations for the 1989 to 2001 period using data from the biennial IPEDS Fall Staff Surveys. ${ }^{3}$ There are a number of important differences in the definition of faculty in the two surveys. One major one is that the Faculty Salary Survey is restricted to faculty with instructional responsibilities, while the Fall Staff Survey also includes faculty without any instructional responsibilities who are

\footnotetext{
${ }^{2}$ The one exception is the Doctoral II category in which the public share is slightly higher than the private share.

${ }^{3}$ Data for 2000 and 2001 are currently not available from the Faculty Salary Survey.
} 
entirely on research or public service appointments. This definitional difference probably leads the share of full-time faculty that is on non tenure-track appointments to be higher in the Staff Survey data.

The tabulations in appendix table 1 are for a sample of 319 public and 761 private 4-year colleges and universities that participated in the Staff Survey each year. While the share of full-time faculty on non tenure tracks is also higher at private institutions than at public institutions in this sample, the increase was greater during the period at the publics than at the privates, due primarily to large increases at the public Research I and Research II institutions. This suggests the growing usage of full-time non tenure-track faculty positions for full-time researchers at these institutions.

In Table 2, we provide some evidence on the growing usage of part-time faculty members. Part-time faculty data is available in the Fall Staff Survey but not in the Faculty Salary Survey. The numbers presented in the table represent the ratio of total part-time faculty members to total full-time faculty members at a set of institutions that were both in the sample each year and reported positive numbers of part-time faculty members in each year. ${ }^{4}$ The ratios are calculated using a sample of 172 public and 483 private institutions.

During the 1989 to 2001 period, the ratio of part-time to full-time faculty members rose from .269 to .377 at the public institutions in the sample and from .499 to .686 at the private institutions in the sample. In 2001, the share of part-time faculty was higher for each Carnegie category of institution at private institutions than it was at public institutions.

\footnotetext{
${ }^{4}$ The latter restriction is necessary because it is impossible to determine whether a blank in the survey data represents zero or missing data in a year. As a result, the shares of full-time faculty members that are parttime may be overstated in these data.
} 
Finally, the Fall Staff Survey also contains information on whether faculty members who are newly hired during the academic year are on tenured, tenure-track or non tenure-track appointments. Remembering that these data include visiting faculty members and faculty members on research or public service appointments who do not have any instructional responsibilities, Table 3 presents information for the 1989 to 2001 period on the shares of new faculty appointments that are neither tenured nor on tenuretracks. These tabulations are for a set of 177 public and 516 private institutions that reported data on new faculty hires each year.

Overall, the share of new full-time faculty appointments not on tenure tracks increased from .460 to .515 at public institutions and from .452 to .573 at private institutions in the sample during the period. Increasingly, new faculty members at 4-year colleges and universities in the United States are being appointed to positions that are not on tenure tracks. ${ }^{5}$

\section{The Demand for Tenure-Track and Non Tenure-Track Faculty Members}

Consider an academic institution, which, for simplicity, hires only two types of faculty members - tenure and tenure-track $\left(\mathrm{F}_{\mathrm{T}}\right)$ and non tenure-track $\left(\mathrm{F}_{\mathrm{N}}\right)$. The latter category includes both full-time and part-time faculty members. The institution is assumed to derive utility from its employment of each category relative to its number of full-time equivalent enrolled students (E).

$$
\text { (1) } \mathrm{U}\left(\mathrm{F}_{\mathrm{T}} / \mathrm{E}, \mathrm{F}_{\mathrm{N}} / \mathrm{E}\right)
$$

Tenured and tenure-track faculty members are important to the academic institution because in addition to teaching, they advise students about their courses of study and

\footnotetext{
${ }^{5}$ The Fall Staff Survey also contains information on the usage of graduate teaching and research assistants. From 1989 to 2001, the usage of graduate assistants, relative to total full-time faculty, increased by about $20 \%$ at both private and public research and doctoral universities.
} 
provide advice and letters of recommendation for postgraduate education and employment opportunities, and they conduct research, share governance responsibilities with the administration and the trustees and provide long-term stability to the institution. Full-time non tenure-track faculty may be important to the institution because, absent the responsibility to produce research, they can be assigned higher teaching loads and can specialize in teaching. Part-time non tenure-track faculty are valuable because in areas in which there is a large supply of people willing to work in such positions they provide the institution with an inventory of instructors who can be hired at the last moment to meet fluctuations in demand. In fields that deal directly with "real world" matters, such as engineering and business, full-time employed professionals willing to teach part-time also provide a type of specialized instruction that institutions might otherwise not be able to offer. In a world in which revenue sources are increasingly uncertain, both types of non tenure-track faculty members provide the academic institution with flexibility to meet rapid changes in its financial situation that the tenure system would otherwise constrain it from having.

Suppose that the average salary per full-time tenured and tenure-track faculty member to the institution is $\mathrm{S}_{\mathrm{T}}$ and the average salary per non tenure-track faculty member is $\mathrm{S}_{\mathrm{N}}$. If the funds per full-time equivalent student that the institution has available to employ faculty are $\mathrm{B} / \mathrm{E}$ and the institution seeks to maximize its utility from hiring faculty members subject to the constraint that the employment budget is exhausted, then the employment demand curves (2) and (3) will result.

(2) $\mathrm{F}_{\mathrm{T}} / \mathrm{E}=\mathrm{F}_{\mathrm{T}} / \mathrm{E}\left(\mathrm{S}_{\mathrm{T}}, \mathrm{S}_{\mathrm{N}}, \mathrm{B} / \mathrm{E}\right)$

(3) $F_{N} / E=F_{N} / E\left(S_{T}, S_{N}, B / E\right)$ 
The employment of each type of faculty per full-time equivalent student will depend upon the salaries for both types of faculty members and the funds that it has available to employ faculty members. Other factors held constant, when a faculty type's average salary level rises, an institution will hire fewer of that type of faculty member and, if its demand for that type of faculty members is elastic (with respect to the faculty type's average salary), it will also substitute more faculty members of the other type. An increase in the per full-time equivalent student faculty employment budget will lead to an increase in both types of faculty members per full-time equivalent student if both types of faculty members are "normal goods" in the institution's utility function. One might conjecture that institutions that do not have a strong research component in their faculty members' portfolio of responsibilities would treat both tenured and tenure-track faculty and non-tenure-track faculty as normal goods. However, institutions that highly value research might treat non tenure-track faculty as "inferior goods" and employ fewer of them as their faculty employment budget expands.

In this section, we employ 9 years of institutional level data that span the fall 1989 to fall 1997 period to estimate variants of equations (2) and (3) for a national sample of 4year colleges and universities. Because no information is available to us on the salaries paid to part-time faculty members, we confine our attention only to the employment of full-time faculty members. Initially, we treat all professorial level faculty (professors, associate professors and assistant professors) as tenured and tenure-track faculty, all lecturers as non tenure-track faculty and exclude instructors from the analyses. ${ }^{6}$ These assumptions allow us to easily compute average faculty salary variables for tenured and

\footnotetext{
${ }^{6}$ We exclude instructors initially because nationally over $15 \%$ of them at Research I and Research II institutions and 25 to $30 \%$ of them at other institutions are tenured or on tenure-track lines.
} 
tenure-track and for non tenure-track faculty members at each institution; however, nationally a small percentage of professorial faculty are actually not on tenure-track lines and a small percentage of lecturers are tenured or on tenure-track lines. Hence, we relax these assumptions below and also include instructors in the analyses.

Table 4 provides estimates of four different specifications of models based upon equations (2) and (3). All are estimated in logarithmic form and include institutional level fixed effects to control for differences in the nature of the curriculum, the research intensity of the institution, and other omitted forces that might influence the usage of different types of faculty members. Inasmuch as the funds available to employ faculty depends upon the revenues coming into the institution, in each equation we replace the per full-time equivalent student faculty employment budget of an institution by its revenues per full-time equivalent student that are available to hire faculty members. ${ }^{7}$

Panel A provides a baseline estimates. The elasticities of both professorial faculty and lecturers with respect to revenue per student are both close to unity. Professorial faculty members' employment is very sensitive to their own salaries, with an elasticity of about minus one, but is insensitive to the salary levels of lecturers. In contrast, lecturers' employment levels are inelastically related to their own salary level and negatively related to the salary levels of professorial faculty. As we shall show, the latter result does not continue to hold in models that allow for lagged adjustment of faculty employment levels to faculty salary levels.

Panel B presents similar estimates for equations that also include year fixedeffects. The latter are included to control for omitted variables that may vary

\footnotetext{
${ }^{7}$ The latter is computed as the total institutional revenue (including tuition and fees, appropriation, grants and contracts, sales and services, and other sources) minus the funding for Pell grants that the institution receives from the federal government.
} 
systematically over time and influence the demand for faculty members. For example, in years in which students' financial need is high, colleges and universities may have to use more funds for institutional grant aid and thus have fewer resources available to employ faculty members. While the inclusion of the year fixed-effects marginally reduces the magnitudes (in absolute value) of the salary elasticities, in the main the results are similar to those in panel A.

The estimates in panels A and B assume that faculty employment levels adjust instantaneously to changes in faculty salaries; however, there may be lags in the adjustment process due to the presence of tenured faculty members and tenure-track and non tenure-track faculty members who are on multi-year contracts. To allow for lagged adjustment, panels $\mathrm{C}$ and $\mathrm{D}$ present estimates of partial adjustment models that included lagged (one year) values of the logarithm of the faculty category's employment level as an additional explanatory variable. ${ }^{8}$ These models are estimated using dynamic estimation methods that control for the endogeneity of the lagged dependent variables. ${ }^{9}$

The coefficient of the lagged dependent variable in the professorial employment equation is very close to zero, suggesting an almost immediate adjustment of tenure and tenure track faculty employment levels to changes in their salary levels. This implies that normal voluntary turnover creates sufficient vacancies each year that adjustment to new desired employment levels can rapidly occur, even when desired employment levels are falling. In contrast, there is evidence of somewhat slower adjustment in the demand for

\footnotetext{
${ }^{8}$ Let $\left(\mathrm{F}_{\mathrm{T}} / \mathrm{E}\right) *$ be the equilibrium level of tenured and tenure-track faculty per student for an institution in year $t$ that results from equation (2) in the text. The partial adjustment model specifies that $\left(\mathrm{F}_{\mathrm{T}} / \mathrm{E}\right)_{\mathrm{t}}-\left(\mathrm{F}_{\mathrm{T}} / \mathrm{E}\right)_{\mathrm{t}-1}=\mathrm{k}\left(\left(\mathrm{F}_{\mathrm{T}} / \mathrm{E}\right)_{\mathrm{t}}-\left(\mathrm{F}_{\mathrm{T}} / \mathrm{E}\right)_{\mathrm{t}-1}\right)$, where $\mathrm{k}$ is the adjustment coefficient. If $\mathrm{k}$ equals one, then full adjustment occurs in one year. If $\mathrm{k}$ is less than one, adjustment to equilibrium is only partial in a year. This model leads to an equation similar to (2), save that the lagged value of tenured and tenure-track employment per student also appears on the right-hand side and this variable's coefficient is equal to one minus $\mathrm{k}$. A similar equation is specified for non tenure-track faculty.

${ }^{9}$ See Manuel Arellano and Stephen Bond (1991).
} 
non tenure-track faculty members. ${ }^{10}$ Moreover, once we allow for lagged adjustment, the own salary elasticities of demand for both tenure and tenure-track faculty members on the one hand, and non tenure-track faculty members on the other hand, become inelastic. In addition, higher salaries for tenured and tenure-track faculty now are seen to lead to an increase in the employment of non tenure-track faculty. ${ }^{11}$

The estimated coefficients in Table 4 come from models in which all professorial faculty are assumed to be tenure or tenure track and all lecturers are assumed to be non tenure-track. In actuality there is a small percentage of non tenure-track faculty members in the professorial groups, a small percentage of tenured and tenure-track faculty members in the lecturer group and instructors, excluded from the analyses in Table 4, are in both groups. It is straightforward for us to accurately compute the employment of tenured and tenure-track faculty members at each institution and the employment of non tenure-track faculty members at each institution from the Faculty Salary Survey data. However, additional assumptions must be made to enable us to obtain estimates of the average salaries of the two different types of faculty at each institution. Specifically, we assume that the average salary of non tenure-track faculty at each rank at an institution is a multiple of the average salary of tenure and tenure-track faculty at the rank at the institution. This multiple is allowed to vary across institutions and over time but is assumed to be constant across ranks at an institution at a point in time. ${ }^{12}$

\footnotetext{
${ }^{10}$ For example, the coefficient of about .15 on the lagged value of lecturer employment implies that about $85 \%$ of the adjustment to the new equilibrium level of lecturer's employment occurs within the one-year period.

${ }^{11}$ We experimented with allowing more complex adjustment processes, such as including lagged values of both faculty employment levels in each faculty employment equation or allowing the speed of adjustment to equilibrium to depend upon the fraction of faculty with tenure or on tenure-tracks. However, these extensions did not improve the fits of our models.

${ }^{12}$ Appendix A provides details of how the average salaries of tenured and tenure-track faculty, on the one hand, and non tenure-track faculty, on the other hand, are computed by us.
} 
Making these assumptions, Table 5 presents estimate similar to those found in Table 4 for the more accurately defined measures of tenured and tenure-track and non tenure-track faculty. The estimated elasticities of both types of faculty employment with respect to revenue per student are much smaller in panels $\mathrm{A}$ and $\mathrm{B}$, than the comparable estimates in Table 4. The own salary elasticities of demand for tenured and tenure-track faculty are now inelastic, while those for non tenure-track faculty are unitary elastic. Increases in tenure-track faculty salaries, holding constant non tenure-track faculty salaries, are associated with higher non tenure-track faculty employment in these models. Panels $\mathrm{C}$ and $\mathrm{D}$ of the table again introduce the possibility of lagged adjustment. Again adjustment of tenured and tenure-track faculty to changes in equilibrium levels is faster than the adjustment of non tenure-track faculty members. As in the first two panels of the table, the own salary elasticity of demand is much larger for non tenure-track faculty than it is for tenure-track faculty and non tenure-track faculty employment levels are positively related to tenure track faculty salaries.

\section{New Hire Equations}

Each year the AAUP collects (but does not publish) information on the number of continuing full-time faculty members (by rank) employed at each academic institution that responds to the AAUP's annual salary survey. ${ }^{13}$ Continuing faculty members in a rank are defined as full-time faculty members who were employed at the university in the rank in the previous year, who are still employed at the university in the current year, regardless of their current ranks.

\footnotetext{
${ }^{13}$ The AAUP salary survey builds on the IPEDS Faculty Salary Survey and faculty members are thus defined in the AAUP survey as faculty members with at least some instructional responsibility.
} 
If one subtracts the number of continuing faculty members at an institution in a rank in a year from the number of faculty members in the rank in the previous year and sums the differences across ranks, one obtains an estimate of the number of full-time vacant faculty positions that potentially could have been filled by new faculty hires at the institution. That is, ignoring changes in the institution's desired faculty employment level caused by changes in enrollments, changes in revenues, or changes in average salaries of faculty members, this vacancy estimate tells us number of full-time faculty new hires that are required in the year to keep full-time faculty employment at the institution constant.

While the AAUP data does not distinguish between "vacancies" that are due to the departure of tenured and tenure-track faculty members and those that are due to the departure of non tenure-track faculty members, it is possible to construct an estimate of each type of vacancy by assuming that the departures of all professorial ranked faculty members are departures of tenure and tenure-track faculty members and that the departures of all instructors are departures of non tenure-track faculty members. ${ }^{14}$ Data on the new hires of full-time faculty members for each institution by tenure and tenuretrack status, but not rank, is available every other year from 1989 in the Fall Staff Survey. As noted above, full-time faculty members are defined differently in this survey than they are in the AAUP Survey or the Faculty Salary Survey because visiting faculty members and faculty members without instructional responsibilities are included in the Fall Staff Survey.

With this proviso in mind, we use the new full-time faculty hire data from the Fall Staff Survey for 1989 to 1997 to estimate equations in which the number of newly hired

\footnotetext{
${ }^{14}$ Sadly the AAUP began collecting continuing faculty data for lecturers only in 1996, so lecturers "vacancies" must be excluded from these analyses
} 
faculty members at an institution who are on tenure or tenure-tracks on the one hand and on non-tenure tracks on the other hand are each assumed to depend upon the number of faculty vacancies at the institution over the period, the increase in revenue per full-time equivalent student received by the institution, the change in its full-time equivalent student body, the logarithm of the average salary of its tenured and tenure-track faculty and the logarithm of the average salary of its non tenure-track faculty members. Models are estimated that both include and exclude year fixed effects. ${ }^{15}$

The estimated coefficients from these models appear in Table 6 . Turning first to the results for new hires of tenured and tenure-track faculty members, the models that use either the number of professorial vacancies at the institution (panels A and B) or those that use the total number of faculty vacancies (including instructors) (panels C and D) perform very similarly. Only a small fraction of all vacancies for full-time faculty members in a year were filled by new hires of tenured and tenure-track faculty members during the year. Increased revenue per student leads to increased full-time tenured and tenure-track new hires, as does increases in the number of full-time equivalent students. However, these variables coefficients are not always statistically significantly different from zero and, at the margin, each increase of 100 full-time equivalent students leads to the hiring of only about 0.2 more full-time tenured and tenure-track faculty members. Higher average salaries for professorial faculty are associated with fewer tenured and tenure-track faculty new hires, but this relationship is statistical significant only in the models that exclude year effects. ${ }^{16}$

\footnotetext{
${ }^{15}$ Institutional fixed effects are required for the reason discussed in appendix A,

${ }^{16}$ As appendix A makes clear, excluding year effects imposes the restriction that the ratio of the average salary of tenured and tenure-track faculty in a rank to the average salary of non tenure-track faculty in a rank at an institution does not vary over time. So this is a very restrictive assumption.
} 
Turning to the results for full-time non tenure-track new hires, non tenure-track new hires are negatively associated with the number of instructor vacancies at an institution and unrelated to the total number of full-time vacancies. The former result may reflect that "vacancies" for instructors are often involuntary in nature; when the demand for them declines, academic institutions fail to reappoint faculty members in the role, which creates "vacancies". Other factors held constant, the greater the number of such vacancies the fewer the number of non tenure-track faculty appointments. Increases in revenues per student are associated with increases in non tenure-track new hires, but changes in fulltime equivalent student employment are not. In the models that include year effects, increases in the average salaries of tenured and tenure-track faculty members are positively and statistically significantly associated with increases in the hiring of non tenure-track faculty. Increases in the average salaries of non tenure-track faculty are negatively associated with fewer full-time non tenure-track faculty hires; however this latter relationship is never statistically significantly different from zero.

\section{Concluding Remarks}

Our paper has presented evidence from a variety of sources that show that during the decade of the 1990s the usage of full-time non tenure-track faculty and part-time faculty continued to grow at four-year colleges and universities in the United States. Lacking data on the salaries of part-time faculty, we could not estimate demand functions for them. However, models of the demand for full-time faculty and for full-time faculty new hires that we did estimate suggest, in the main, that as the salaries of full-time non-tenure 
track faculty decline relative to the salaries of full-time tenure and tenure-track faculty, the relative usage of full-time non tenure-track faculty will increase.

Between 1989 and 1997, the ratio of the average salary of lecturers to the average salary of all professorial faculty members at four-colleges and universities in the United States declined from .642 to .607 in the Faculty Salary Survey data. This suggests that declining relative salaries of full-time non tenure-track faculty members played a role in their increasing relative usage during the period. ${ }^{17}$ Four-year American colleges and universities have been able to attract lecturers at salaries that have been falling relative to their tenure track colleagues' salaries because of the large number of PhDs available to fill such positions in many fields. However, this does not imply that lecturers and other full-time non tenure-track faculty members are happy in their roles and the growing salary gap between them and their tenured and tenure-track counterparts is undoubtedly one of the main forces leading to efforts by various unions to unionize full-time nontenure track faculty members. ${ }^{18}$ Hence, the relative cost advantage of full-time non-tenure track faculty members may diminish in the future.

Of course parents of college age students, taxpayers more generally, state legislators and governors and the trustees of private colleges and universities may reasonably ask why they should be concerned about the growing use of part-time and

\footnotetext{
${ }^{17}$ As we have discussed above, not all lecturers are non tenure-track, not all professorial faculty are on tenured or tenure-track lines and instructors (left out of the computation of the ratio) are employed on all three types of appointments. However, we can not more accurately estimate how the average salary of fulltime non tenure-track faculty members has changed vis-à-vis the average salary of their tenured and tenuretrack counterparts because the method we used to compute relative salaries of the two groups to conduct the estimation that led to table 5 required us to assume that in a given year the ratio of salaries of the two groups at an institution were constant across ranks, but varied across institutions. These ratios were treated as unobserved institutional fixed effects that were subsumed in the more general fixed effects in our model. ${ }^{18}$ By way of an example, in May 2003 non-tenure track faculty members at the University of Michigan voted to create a union to represent the 1300 full-time and part-time non-tenure track faculty at the university (Smallwood 2003).
} 
full-time non tenure track faculty members. Surprisingly, very few studies have addressed whether the increased substitution of part-time and full-time non tenure-track faculty for tenure-track faculty at higher education institutions leads to adverse academic outcomes for undergraduate students, such as less learning in any class, longer times to degree, lower graduation rates, or a lower proportion of graduates going on to postgraduate study. Analyses of these issues will be essential if public institutions want to make the case to their state legislators and governors and private academic institutions want to make the case to their trustees that better funding would enable them to increase their usage of tenure-track faculty members and that this would enhance undergraduate students' educational outcomes. ${ }^{19}$

Finally, it is well known that the proportion of PhDs granted by U.S universities that go to American citizens has been falling over long periods of time. In some science and engineering fields and in economics, the proportion of PhDs granted to American citizens is now well under $50 \% .{ }^{20}$ Universities and public policy makers would do well to contemplate what the likely affect of their increased usage of part-time and full-time non tenure-track faculty is on the desire of American college graduates to go on to $\mathrm{PhD}$ study. Put more starkly, by increasing their reliance on non tenure-track faculty, American

\footnotetext{
${ }^{19}$ One study of community college students that randomly assigned them to sections of a remedial mathematics course that were taught by part-time and tenure-track full-time faculty found no differences in the amounts that student learned (Bolge 1995). Another study of a Midwestern comprehensive institution found, using four years of data on fall entering freshman, that the greater the proportion of part-time faculty that students had during their first semester in college, the lower the probability that they would return for their second semester (Harrington and Schibik 2001). Studies by economists have tended to focus on how instructor type (including graduate students) influences the amount that students learn in first-year classes (Finegan and Siegfried 1998, Lynch and Watts, 1989) and the results vary across studies. Bettinger and Long (2003) are using data from Ohio public 4-year colleges to study the impact of adjunct faculty (as compared to full-time faculty regardless of tenure or tenure-track status) and their preliminary results suggest that adjuncts do not have negative effects on undergraduate students.

${ }^{20}$ See for example, John Siegfried and Wendy Stock (2004)
} 
colleges and universities may be making PhD study a less attractive option than would otherwise by the case. 


\section{References}

Eugene L. Anderson, The New Professoriate: Characteristics, Contributions and

Compensation (Washington DC: American Council on Education, 2002)

Manuel Arellano and Stephen Boyd, "Some Tests of Specification for Panel Data:

Monte Carol Evidence and an Application to Employment Equations", Review of

Economic Studies 58 (April 1991): 277-297

Roger G. Baldwin and Jay L. Chronister, Teaching Without Tenure: Policies and Practices for a New Era (Baltimore MD: Johns Hopkins Press, 2001)

Eric Bettinger and Bridget Terry Long, "The Effects of Adjunct Professors on Student Outcomes" (preliminary draft of a paper presented at the NBER Labor Studies Summer Workshop, July 2003)

Robert D. Bolge, "Examination of Student Learning as a Function of Instructor Status (Full-time vs. Part-Time) at Mercer County Community College" (unpublished paper, Mercer County Community College, 1995), available from ERIC (ED382241)

Valerie M. Conley, David W. Leslie and Linda J. Zimbler, Part-Time

Instructional Faculty and Staff: Who They Are, What They Do, and What They Think

(Washington DC: U.S. Department of Education, 2002)

Ronald G. Ehrenberg, Michael J. Rizzo and George H. Jakubson, "Who Bears the Growing Cost of Science at Universities?", National Bureau of Economic Research Working Paper 9627 (Cambridge MA: April 2003)

T. Aldrich Finegan and John J. Siegfried, "Do Introductory Economics Students Learn More if Their Instructor Has a PhD?”, American Economist 42 (Fall 1998): 34-46 
Charles Harrington and Timothy Schibik, "Caveat Emptor: Is There a

Relationship Between Part-Time Faculty Utilization and Student Learning Outcomes and Retention". Paper presented at the $41^{\text {st }}$ Annual Meeting of the Association for Institutional Research (Long Beach CA, June 2001

John J. Siegfried and Wendy A. Stock, “The Market for New PhD Economists in 2002" (paper presented at the Allied Social Science Associations Meeting, San Diego

CA, January 2004)

Scott Smallwood, "Non-Tenure-Track Faculty Members Vote to Unionize at U. of Michigan”, Chronicle of Higher Education 49 (May 9, 2003): A15 Michael Watts and Gerald J. Lynch, "The Principles Courses Revisited", American Economic Review 79 (May 1989): 236 - 241 
Table 1

Full time non-tenure track faculty / Total full time faculty

\begin{tabular}{|c|c|c|c|c|c|c|c|c|c|c|c|}
\hline PUBLIC (sample size) & 89 & 90 & 91 & 92 & 93 & 94 & 95 & 96 & 97 & 98 & $99^{\mathrm{a}}$ \\
\hline Research I (59) & 0.099 & 0.100 & 0.099 & 0.099 & 0.097 & 0.101 & 0.099 & 0.102 & 0.112 & 0.121 & 0.128 \\
\hline Research II (26) & 0.109 & 0.105 & 0.100 & 0.095 & 0.094 & 0.096 & 0.096 & 0.102 & 0.112 & 0.120 & 0.123 \\
\hline Doctoral I (28) & 0.117 & 0.117 & 0.114 & 0.110 & 0.116 & 0.119 & 0.121 & 0.124 & 0.128 & 0.149 & 0.160 \\
\hline Doctoral II (38) & 0.121 & 0.126 & 0.129 & 0.125 & 0.121 & 0.128 & 0.121 & 0.132 & 0.133 & 0.139 & 0.149 \\
\hline Comprehensive I (246) & 0.111 & 0.117 & 0.108 & 0.111 & 0.107 & 0.109 & 0.111 & 0.114 & 0.124 & 0.128 & 0.138 \\
\hline Comprehensive II (25) & 0.148 & 0.138 & 0.129 & 0.153 & 0.133 & 0.129 & 0.129 & 0.127 & 0.135 & 0.131 & 0.160 \\
\hline Liberal Arts I (7) & 0.213 & 0.220 & 0.203 & 0.180 & 0.157 & 0.116 & 0.120 & 0.125 & 0.103 & 0.092 & 0.103 \\
\hline Liberal Arts II (75) & 0.134 & 0.131 & 0.134 & 0.140 & 0.147 & 0.138 & 0.139 & 0.135 & 0.141 & 0.153 & 0.165 \\
\hline Total & 0.110 & 0.112 & 0.108 & 0.108 & 0.107 & 0.109 & 0.109 & 0.112 & 0.121 & 0.128 & 0.137 \\
\hline PRIVATE (sample size) & 89 & 90 & 91 & 92 & 93 & 94 & 95 & 96 & 97 & 98 & $99^{\mathrm{a}}$ \\
\hline Research I (29) & 0.124 & 0.173 & 0.148 & 0.171 & 0.167 & 0.159 & 0.166 & 0.172 & 0.151 & 0.156 & 0.154 \\
\hline Research II (11) & 0.065 & 0.083 & 0.078 & 0.089 & 0.095 & 0.108 & 0.113 & 0.118 & 0.121 & 0.128 & 0.127 \\
\hline Doctoral I (23) & 0.092 & 0.105 & 0.107 & 0.102 & 0.088 & 0.161 & 0.141 & 0.154 & 0.163 & 0.180 & 0.194 \\
\hline Doctoral II (22) & 0.123 & 0.096 & 0.107 & 0.102 & 0.141 & 0.123 & 0.090 & 0.107 & 0.115 & 0.132 & 0.141 \\
\hline Comprehensive I (180) & 0.146 & 0.171 & 0.165 & 0.182 & 0.190 & 0.181 & 0.189 & 0.193 & 0.203 & 0.193 & 0.221 \\
\hline Comprehensive II (65) & 0.186 & 0.258 & 0.253 & 0.265 & 0.260 & 0.215 & 0.223 & 0.223 & 0.225 & 0.233 & 0.226 \\
\hline Liberal Arts I (156) & 0.109 & 0.102 & 0.095 & 0.097 & 0.098 & 0.099 & 0.102 & 0.109 & 0.115 & 0.119 & 0.130 \\
\hline Liberal Arts II (368) & 0.226 & 0.244 & 0.250 & 0.259 & 0.275 & 0.284 & 0.275 & 0.277 & 0.288 & 0.295 & 0.306 \\
\hline Total & 0.142 & 0.165 & 0.158 & 0.169 & 0.175 & 0.176 & 0.176 & 0.182 & 0.184 & 0.187 & 0.197 \\
\hline
\end{tabular}

Source: National Center for Educational Statistics (NCES) IPEDS Faculty Salary Survey (available at WEBCaspar, http://caspar.nsf.gov)

${ }^{a}$ The estimates for 1999 are based on preliminary data released by NCES 
Table 2

Part-time faculty / Total full time faculty

\begin{tabular}{lrrrrrrr}
\hline PUBLIC (sample size) & 89 & 91 & 93 & 95 & 97 & $99^{\mathrm{a}}$ & $01^{\mathrm{a}}$ \\
\hline Research I (50) & 0.211 & 0.195 & 0.229 & 0.222 & 0.285 & 0.268 & 0.260 \\
Research II (22) & 0.153 & 0.214 & 0.175 & 0.197 & 0.201 & 0.224 & 0.219 \\
Doctoral I (23) & 0.304 & 0.316 & 0.364 & 0.358 & 0.348 & 0.394 & 0.352 \\
Doctoral II (34) & 0.335 & 0.234 & 0.329 & 0.380 & 0.407 & 0.455 & 0.503 \\
Comprehensive I (174) & 0.350 & 0.352 & 0.397 & 0.415 & 0.454 & 0.478 & 0.541 \\
Comprehensive II (10) & 0.372 & 0.387 & 0.383 & 0.373 & 0.456 & 0.557 & 0.484 \\
Liberal Arts I (2) & $*$ & $*$ & $*$ & $*$ & $*$ & $*$ & $*$ \\
Liberal Arts II (37) & 0.484 & 0.558 & 0.611 & 0.658 & 0.674 & 0.667 & 0.631 \\
Total & $\mathbf{0 . 2 6 9}$ & $\mathbf{0 . 2 6 3}$ & $\mathbf{0 . 2 9 8}$ & $\mathbf{0 . 3 0 6}$ & $\mathbf{0 . 3 4 7}$ & $\mathbf{0 . 3 6 5}$ & $\mathbf{0 . 3 7 7}$ \\
\hline PRIVATE (sample size) & 89 & 91 & 93 & 95 & 97 & $99^{\mathrm{a}}$ & $01^{\mathrm{a}}$ \\
\hline Research I (22) & 0.215 & 0.300 & 0.387 & 0.440 & 0.494 & 0.329 & 0.416 \\
Research II (8) & 0.430 & 0.351 & 0.410 & 0.418 & 0.406 & 0.464 & 0.420 \\
Doctoral I (12) & 0.792 & 0.631 & 0.694 & 0.702 & 1.043 & 1.127 & 0.923 \\
Doctoral II (13) & 0.551 & 0.634 & 0.633 & 0.780 & 0.816 & 0.643 & 0.643 \\
Comprehensive I (109) & 0.909 & 0.882 & 0.945 & 1.032 & 1.016 & 1.045 & 1.186 \\
Comprehensive II (36) & 0.708 & 0.745 & 1.083 & 1.116 & 1.239 & 0.903 & 0.949 \\
Liberal Arts I (111) & 0.309 & 0.330 & 0.367 & 0.349 & 0.391 & 0.320 & 0.358 \\
Liberal Arts II (172) & 0.685 & 0.766 & 0.852 & 0.887 & 0.947 & 0.788 & 0.885 \\
Total & $\mathbf{0 . 4 9 9}$ & $\mathbf{0 . 5 3 2}$ & $\mathbf{0 . 5 9 9}$ & $\mathbf{0 . 6 4 3}$ & $\mathbf{0 . 6 9 7}$ & $\mathbf{0 . 6 2 2}$ & $\mathbf{0 . 6 8 6}$ \\
\hline
\end{tabular}

Source: National Center for Educational Statistics, IPEDS Fall Staff Survey

${ }^{\mathrm{a}}$ The numbers for 1999 and 2001 are from preliminary data released by the NCES

* Proportions not reported because of the small sample size 
Table 3

Non-tenured new hires / Total new hires

\begin{tabular}{lrrrrrrr}
\hline PUBLIC (sample size) & 89 & 91 & 93 & 95 & 97 & $99^{\mathrm{a}}$ & $01^{\mathrm{a}}$ \\
\hline Research I (53) & 0.543 & 0.546 & 0.575 & 0.558 & 0.622 & 0.684 & 0.573 \\
Research II (25) & 0.411 & 0.372 & 0.501 & 0.475 & 0.545 & 0.524 & 0.523 \\
Doctoral I (22) & 0.481 & 0.565 & 0.495 & 0.461 & 0.495 & 0.564 & 0.514 \\
Doctoral II (31) & 0.377 & 0.418 & 0.509 & 0.516 & 0.536 & 0.505 & 0.502 \\
Comprehensive I (191) & 0.395 & 0.382 & 0.410 & 0.410 & 0.429 & 0.435 & 0.429 \\
Comprehensive II (17) & 0.410 & 0.357 & 0.385 & 0.314 & 0.415 & 0.488 & 0.532 \\
Liberal Arts I (3) & 0.449 & 0.577 & 0.559 & 0.382 & 0.531 & 0.339 & 0.451 \\
Liberal Arts II (41) & 0.404 & 0.398 & 0.393 & 0.450 & 0.411 & 0.435 & 0.566 \\
Total & $\mathbf{0 . 4 6 0}$ & $\mathbf{0 . 4 6 0}$ & $\mathbf{0 . 4 9 4}$ & $\mathbf{0 . 4 8 5}$ & $\mathbf{0 . 5 2 9}$ & $\mathbf{0 . 5 6 5}$ & $\mathbf{0 . 5 1 5}$ \\
\hline PRIVATE (sample size) & 89 & 91 & 93 & 95 & 97 & $99^{\mathrm{a}}$ & $01^{\mathrm{a}}$ \\
\hline Research I (25) & 0.636 & 0.594 & 0.630 & 0.602 & 0.708 & 0.656 & 0.700 \\
Research II (10) & 0.409 & 0.511 & 0.536 & 0.459 & 0.460 & 0.457 & 0.423 \\
Doctoral I (16) & 0.528 & 0.466 & 0.562 & 0.568 & 0.528 & 0.413 & 0.641 \\
Doctoral II (13) & 0.328 & 0.324 & 0.456 & 0.588 & 0.416 & 0.452 & 0.499 \\
Comprehensive I (117) & 0.351 & 0.476 & 0.416 & 0.507 & 0.418 & 0.526 & 0.461 \\
Comprehensive II (39) & 0.310 & 0.351 & 0.477 & 0.451 & 0.359 & 0.441 & 0.443 \\
Liberal Arts I (119) & 0.427 & 0.447 & 0.494 & 0.508 & 0.556 & 0.563 & 0.583 \\
Liberal Arts II (177) & 0.281 & 0.302 & 0.386 & 0.360 & 0.405 & 0.448 & 0.547 \\
Total & $\mathbf{0 . 4 5 2}$ & $\mathbf{0 . 4 7 3}$ & $\mathbf{0 . 5 0 3}$ & $\mathbf{0 . 5 1 8}$ & $\mathbf{0 . 5 2 6}$ & $\mathbf{0 . 5 4 2}$ & $\mathbf{0 . 5 7 3}$ \\
\hline
\end{tabular}

Source: National Center for Education Statistics, IPEDS Fall Staff Survey

${ }^{\text {a }}$ The numbers for 1999 and 2001 are from preliminary data released by NCES 
Table 4

Logarithmic Faculty Demand Functions Estimates: Instructors Excluded ${ }^{\mathrm{a}}$ ( $\mathrm{t}$ statistics in parentheses)

$\begin{array}{cc}\text { Log (All Professorial } & \text { Log (Lecturers per } \\ \text { Faculty per Student) } & \text { Student) }\end{array}$

\begin{abstract}
A) Without year effects Log (Ave. All Prof. Faculty Salary)

Log (Ave. Lecturer Salary)

Log (Revenue Per Student)

$\mathrm{R}^{2}$

$\mathrm{N}$
\end{abstract}

\begin{aligned} &-1.0667$(-27.27) \\ & 0.0154(0.64) \\ & 0.8216(58.55) \\ & 0.9428 \\ & 2019 \\ &$\hline\end{aligned}

$-0.7244 \quad(-5.65)$

$-0.1933 \quad(-2.48)$
$-0.9645 \quad(-22.89)$
$0.0157 \quad(0.67)$
$0.8409 \quad(59.6)$
0.9449
2019

$-0.5435 \quad(-3.88)$

$-0.1853 \quad(-2.38)$

$0.8586 \quad(18.32)$

Log (Revenue Per Student)

0.9117

$\mathrm{R}^{2}$

2019

\title{
C) Without year effects
}

Lagged Dependent Variable

Log (Ave. All Prof. Faculty Salary)

\begin{aligned} & 0.0430$(2.23) \\ &-0.2291(-3.08) \\ &-0.0041(-0.20) \\ & 0.6659(21.09) \\ & 459 \\ & 1326 \\ &$\hline\end{aligned}

0.8375 (18.23)

0.9109

2019

Log (Ave. Lecturer Salary)

Log (Revenue Per Student)

Wald chi2

$0.1461 \quad(4.07)$

$0.6330 \quad(1.99)$

$-0.1911 \quad(-2.21)$

$\mathrm{N}$
D) With year effects
Lagged Dependent Variable
Log (Ave. All Prof. Faculty Salary)
Log (Ave. Lecturer Salary)
Log (Revenue Per Student)
Wald chi2
$\mathrm{N}$

$\begin{aligned} 0.0079 & (0.46) \\ -0.2986 & (-4.08) \\ -0.0011 & (-0.06) \\ 0.6561 & (21.27) \\ 480 & \\ 1326 & \end{aligned}$

$0.5510 \quad(4.09)$

43

1291

\footnotetext{
${ }^{a}$ All professorial faculty are considered tenured and tenure-track faculty and all lecturers are considered non tenure-track faculty. Instructors are excluded from the analyses
} 
Table 5

Logarithmic Faculty Demand Functions: Tenure-Track Status Correctly Assigned ( $\mathrm{t}$ statistics are in parentheses)

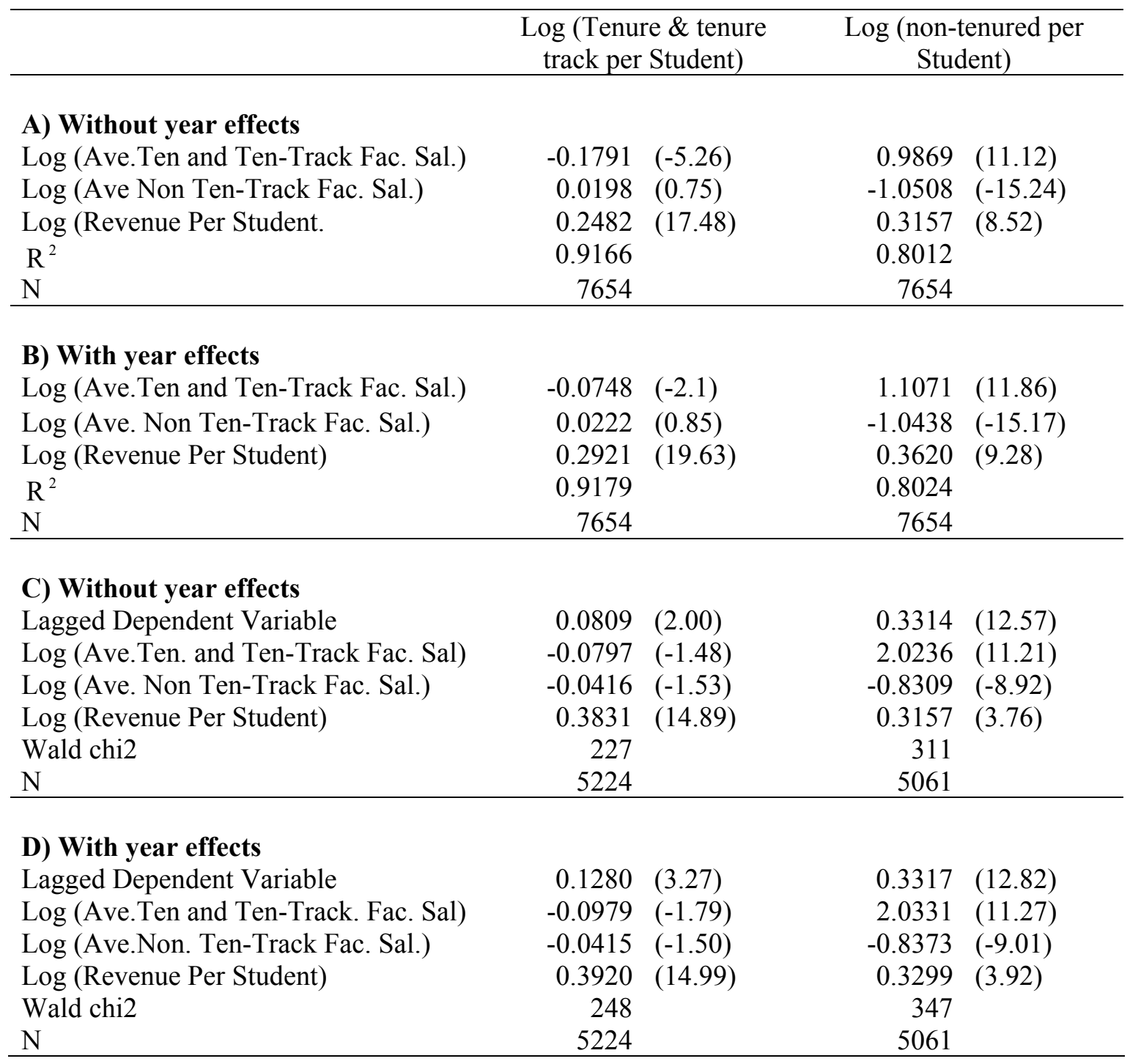


Table 6

Full-Time Faculty New Hire Equations ${ }^{\mathrm{a}}$

(t statistics are in parentheses)

New hire tenure $\&$ tenure New hire non-tenure track track faculty faculty

\section{A) without year effects}

Professorial vacancies

$0.0440 \quad(2.32)$

Instructor vacancies

Revenue change per FTE in 1,000

$-0.2814 \quad(-2.6)$

FTE change in 100

$0.2322 \quad(1.35)$

$0.4921 \quad(2.06)$

$0.2126(2.13)$

$0.0523(0.38)$

Log (Ave Ten. and Ten-Track Fac. Sal.)

$-14.6044 \quad(-2.75)$

$6.4247(0.87)$

Log (Ave. Non Tenure-Track Fac. Sal.)

$2.1517(0.58)$

$-2.1235 \quad(-0.41)$

$\mathrm{R}^{2}$

0.8436

0.8365

1868

1868

\section{B) with year effects}

Professorial vacancies

$0.0403 \quad(2.11)$

Instructor vacancies

Revenue change per FTE in 1,000

$\begin{array}{lll}0.2923 & (-2.7)\end{array}$

FTE change in 100

$0.1901 \quad(1.09)$

$0.5162(2.14)$

$0.1744 \quad(1.72)$

$0.0461 \quad(0.33)$

Log (Ave Ten. and Ten-Track Fac. Sal.)

$-1.3842(-0.14)$

$32.8974(2.42)$

Log (Ave. Non Tenure-Track Fac. Sal.)

$2.6754(0.72)$

$-1.3754 \quad(-0.27)$

$\mathrm{R}^{2}$

0.8443

0.8375

$\mathrm{N}$

1868

1868

\section{C) Without year effects}

Total vacancies

Revenue change per FTE in 1,000

FTE change in 100

Log (Ave Ten. and Ten-Track Fac. Sal)

Log (Ave. Non Tenure-Track Fac. Sal)

$\mathrm{R}^{2}$

$\mathrm{N}$

$\begin{aligned} 0.0315 & (1.8) \\ 0.2242 & (1.3) \\ 0.2155 & (2.16) \\ -14.4818 & (-2.73) \\ 2.2026 & (0.6) \\ 0.8432 & \\ 1868 & \end{aligned}$

$-0.0098 \quad(-0.4)$

$0.4744 \quad(1.98)$

$0.0722(0.52)$

$7.8810 \quad(1.07)$

$-2.0518(-0.4)$

0.8354

1868

\section{D) With year effects}

Total vacancies

Revenue change per FTE in 1,000

$0.0275 \quad(1.57)$

$-0.0091 \quad(-0.37)$

$0.1808 \quad(1.04)$

$0.5025 \quad(2.08)$

FTE change in 100

0.1762 (1.73)

$0.0712(0.5)$

Log (Ave Ten. and Ten-Track Fac. Sal)

$-1.3129 \quad(-0.13)$

$32.5641 \quad(2.39)$

Log (Ave Non tenure Track Fac. Sal.)

$2.7293(0.74)$

$-1.3725 \quad(-0.27)$

$\mathrm{R}^{2}$

0.8440

0.8363

1868

1868

${ }^{\mathrm{a}}$ Institutional Fixed Effects are included in each equation 
Appendix Table 1

Full time non-tenure track faculty / Total full time faculty,

\begin{tabular}{lrrrrrrr}
\hline PUBLIC (sample size) & 89 & 91 & 93 & 95 & 97 & $99^{\mathrm{a}}$ & $01^{\mathrm{a}}$ \\
\hline Research I (53) & 0.245 & 0.253 & 0.263 & 0.286 & 0.332 & 0.356 & 0.375 \\
Research II (25) & 0.183 & 0.171 & 0.179 & 0.192 & 0.233 & 0.244 & 0.274 \\
Doctoral I (27) & 0.160 & 0.193 & 0.191 & 0.202 & 0.213 & 0.235 & 0.237 \\
Doctoral II (34) & 0.176 & 0.176 & 0.200 & 0.206 & 0.212 & 0.226 & 0.240 \\
Comprehensive I (229) & 0.133 & 0.133 & 0.132 & 0.129 & 0.141 & 0.153 & 0.179 \\
Comprehensive II (21) & 0.181 & 0.141 & 0.132 & 0.119 & 0.146 & 0.182 & 0.199 \\
Liberal Arts I (4) & 0.134 & 0.110 & 0.140 & 0.125 & 0.117 & 0.109 & 0.121 \\
Liberal Arts II (61) & 0.213 & 0.211 & 0.187 & 0.202 & 0.195 & 0.223 & 0.242 \\
Total & $\mathbf{0 . 1 9 1}$ & $\mathbf{0 . 1 9 4}$ & $\mathbf{0 . 2 0 1}$ & $\mathbf{0 . 2 1 2}$ & $\mathbf{0 . 2 4 1}$ & $\mathbf{0 . 2 6 0}$ & $\mathbf{0 . 2 8 1}$ \\
\hline PRIVATE (sample size) & 89 & 91 & 93 & 95 & 97 & $99^{\mathrm{a}}$ & $01^{\mathrm{a}}$ \\
\hline & & & & & & & \\
Research I (26) & 0.312 & 0.358 & 0.344 & 0.335 & 0.410 & 0.432 & 0.434 \\
Research II (11) & 0.173 & 0.165 & 0.186 & 0.180 & 0.196 & 0.222 & 0.230 \\
Doctoral I (19) & 0.233 & 0.193 & 0.231 & 0.212 & 0.234 & 0.256 & 0.274 \\
Doctoral II (15) & 0.132 & 0.122 & 0.153 & 0.137 & 0.144 & 0.159 & 0.191 \\
Comprehensive I (164) & 0.188 & 0.197 & 0.195 & 0.207 & 0.212 & 0.242 & 0.254 \\
Comprehensive II (58) & 0.207 & 0.199 & 0.216 & 0.227 & 0.220 & 0.239 & 0.230 \\
Liberal Arts I (149) & 0.155 & 0.158 & 0.149 & 0.149 & 0.154 & 0.173 & 0.183 \\
Liberal Arts II (319) & 0.287 & 0.294 & 0.297 & 0.292 & 0.286 & 0.321 & 0.328 \\
Total & $\mathbf{0 . 2 3 5}$ & $\mathbf{0 . 2 4 8}$ & $\mathbf{0 . 2 5 0}$ & $\mathbf{0 . 2 4 8}$ & $\mathbf{0 . 2 7 5}$ & $\mathbf{0 . 3 0 1}$ & $\mathbf{0 . 3 0 9}$
\end{tabular}

Source: National Center for Education Statistics, IPEDS Fall Staff Survey

${ }^{a}$ The numbers for 1999 and 2001 are from the preliminary data released by NCES. 


\section{Appendix A}

Let $F_{i j t}$ be the number of faculty members of rank $i$ at institution $j$ in year $t$. Let $f_{i j t}$ be the fraction of faculty members of rank $i$ at institution $j$ in year $t$ that have tenured or tenure-track appointments. Finally, let $\mathrm{S}_{\mathrm{ijt}}$ be the average salary of faculty members of rank $i$ at institution $j$ in year $t$. Then the number of faculty members at institution $j$ with tenured or tenure track appointments in year $t$ is simply the sum over all ranks (i) of $F_{i j t} f_{i j t}$ and the number of faculty members on non tenure-track appointments is simply the sum over all ranks (i) of $F_{i j t}\left(1-f_{i j t}\right)$. Each of these sums can be directly calculated from the Faculty Salary Survey data. Put another way, we know from the data the number of tenured and tenure-track and the number of non tenure-track faculty members at each institution in each year.

We know the average salary of faculty members of each rank at each institution in each year. We do not have information on the average salary of faculty members at each rank in each year by tenure-track status. However, if an estimate of these numbers can be obtained if one is willing to assume that the average salary of tenured and tenure track faculty at a rank is a constant multiple of the average salary of non tenure-track faculty at the rank. This multiple is assumed to be constant across ranks at a given institution over time but is allowed to vary over time. That is, letting the subscript $\mathrm{T}$ represent tenured and tenure-track faculty and the subscript $\mathrm{N}$ non tenure-track faculty, we assume

(A1) $\mathrm{S}_{\mathrm{ijtT}}=\mathrm{m}_{\mathrm{jt}} \mathrm{S}_{\mathrm{itjN}}$

and

(A2) $m j t=b_{i} d_{t}$. 
It immediately follows that the average salary of tenure and tenure track faculty members across all ranks at institution $i$ at time $t\left(\mathrm{~S}_{\mathrm{itT}}\right)$ is given by the sum across all ranks of $\mathrm{S}_{\mathrm{ijt}} \mathrm{b}_{\mathrm{i}} \mathrm{d}_{\mathrm{t}} \mathrm{F}_{\mathrm{ijf}} \mathrm{f}_{\mathrm{ijt}}$ divided by total tenured and tenure track faculty employment at the institution. The average salary of non tenure-track faculty members at the institutions is similarly calculated by replacing the $\mathrm{f}_{\mathrm{ijt}}$ by $\left(1-\mathrm{f}_{\mathrm{ijt}}\right)$ in the expression above All of the variables in each of these two expressions are known numbers save for $b_{i}$ and $d_{t}$ which are treated as parameters that vary across institutions and over years. When one takes the logarithm of each average salary expression, as is done when we estimate logarithmic demand equations (table 5) and new hire equations (table 6), the logarithm of each average salary is equal to the sum of the logarithm of a known number and the logarithms of an institutional and a year effect. Hence the $b_{i}$ and $d_{t}$ are subsumed in the institutional and time fixed effects. 